Dunamis: Jurnal Teologi dan Pendidikan Kristiani

Volume 3, Nomor 2 (April 2019)

ISSN 2541-3937 (print), 2541-3945 (online)

http://www.sttintheos.ac.id/e-journal/index.php/dunamis

Submitted: 20 Desember 2018

Accepted: 26 Februari 2019

Published: 29 April 2019

\title{
Kesadaran Akan Allah Melalui Penderitaan Berdasarkan Ayub 1-2
}

\author{
Kalis Stevanus \\ Sekolah Tinggi Teologi Tawangmangu \\ kalisstevanus91+@gmail.com
}

\begin{abstract}
This article was a biblical analysis of the awareness of God through suffering in the book of Job chapter 1 and 2. The subject's very important to be reviewed in considering the context of the suffering of believers at present. The aim of this biblical analysis was not only touching theological dimension, but ultimately to change the hypothetical into the realm of practical life, where suffering believers could gain the power of faith. The research method used in this study was the method of narrative analysis or narrative criticism of Job chapter 1 and 2. Through this study it could be concluded that God is sovereign over everything and no incident happens by chance, but there is a plan of God in it. Therefore, reflecting on Job's experience, it is important to carry out self-reflection as well as surrender so that in the end it does not experience despair in the midst of suffering.
\end{abstract}

Keywords: Book of Job; awareness of God; suffering

\begin{abstract}
Abstrak
Tulisan ini merupakan sebuah analisis biblikal tentang kesadaran akan Allah melalui penderitaan di dalam kitab Ayub pasal 1 dan 2. Pokok bahasan ini sangat penting untuk dikaji kembali dengan mempertimbangkan konteks penderitaan orang percaya di masa kini. Tujuan analisis biblikal ini diharapkan tidak hanya menyentuh dimensi teologis, tetapi pada akhirnya mengubah yang hipotetis ke dalam lingkup kehidupan praktis, di mana orang-orang percaya yang menderita dapat beroleh kekuatan iman. Metode penelitian yang digunakan dalam kajian ini adalah metode analisis naratif atau kritik naratif terhadap Ayub pasal 1 dan 2 . Melalui kajian ini dapat disimpulkan bahwa Allah berdaulat atas segala sesuatu dan tidak ada peristiwa yang terjadi secara kebetulan, tapi ada rencana Tuhan di dalamnya. Oleh karenanya, bercermin dari pengalaman Ayub tersebut, penting melakukan refleksi diri dan sekaligus penyerahan diri sehingga pada akhirnya tidak mengalami keputusasaan di tengah penderitaan.
\end{abstract}

Kata Kunci: Kitab Ayub; kesadaran akan Allah; penderitaan 


\section{PENDAHULUAN}

Ada dua jenis pengetahuan, yakni knowledge by description (pengetahuan tentang sesuatu melalui bacaan atau orang lain) dan knowledge by experience (adanya pengetahuan dalam hubungan langsung dengan hal yang riil). Seseorang dapat memiliki kesadaran atau pengetahuan tentang keberadaan Allah melalui wahyu Tuhan yang tertulis di dalam Kitab Suci (knowledge by description), tetapi juga ada jalan lain, yaitu melalui pengalaman (knowledge by experience). Pengalaman manusia tentang Allah akan membentuk suatu pengetahuan tentang Allah.

Kesadaran akan Allah di dalam kehidupan manusia semakin nampak atau terlihat ketika ia mengalami masalah atau kesulitan hidup. Manusia kembali memikirkan tentang Allah ketika ia mengalami kesulitan hidup. Persoalan hidup manusia selalu terkait dengan kesadaran manusia tentang keberadaan Allah. Kesadaran manusia memengaruhi bagaimana mereka bertingkah laku dan bertindak dalam setiap pengambilan keputusan mereka. Peniel C.D. Maiaweng dan Christina Ukung ${ }^{1}$ memberikan contoh

\footnotetext{
${ }^{1}$ Peniel C.D. Maiaweng, Christina Ukung, and Christina Ukung, "Apakah Rut, Perempuan Moab Adalah Penyembah TUHAN?," Jurnal Jaffray 16, no. 2 (October 3, 2018): 161, accessed April 5, 2019 ,
}

konkrit mengenai kesadaran akan Allah ialah yang ada di dalam diri Ruth perempuan Moab yang memutuskan mengikuti Naomi ke Bethelehem dan menjadi penyembah Tuhan. Naomi meminta Rut untuk pulang mengikuti iparnya, tetapi jawaban Rut kepada Naomi, "Janganlah desak aku meninggalkan engkau dan pulang dengan tidak mengikuti engkau; sebab ke mana engkau pergi, ke situ jugalah aku pergi, dan di mana engkau bermalam, di situ jugalah aku bermalam: bangsamulah bangsaku dan Allahmulah Allahku; di mana engkau mati, akupun mati di sana, dan di sanalah aku dikuburkan. Beginilah kiranya TUHAN menghukum aku, bahkan lebih lagi dari pada itu, jikalau sesuatu apapun memisahkan aku dari engkau, selain dari pada maut!" (1:15-17).

Kesadaran akan Allah merupakan kesadaran tertinggi manusia untuk memahami dan bertindak sesuai pemahamannya tentang Allah terhadap segala sesuatu yang dialami di dalam hidupnya. Pengalaman religius seseorang akan memengaruhi konsepsinya (pengertiannya) dan membangkitkan kesadaran akan Allah dalam memaknai pengalaman hidupnya, termasuk

http://ojs.sttjaffray.ac.id/index.php/JJV71/article/vie w/308. 
penderitaan. Benar, apa yang dikatakan Elvin Atmaja Hidayat bahwa penderitaan merupakan problem iman. Ada orang dapat menerima penderitaannya dan menjadi semakin beriman saat diuji dalam penderitaan, sementara yang lain tidak dapat menerimanya dan kehilangan iman. Bagi orang yang tidak dapat menerima penderitaan hidupnya, Allah yang Mahakasih dianggap sebagai semacam konsep tipuan atau khayalan, sehingga kurang diimani, karena dianggap tidak membantu. ${ }^{2}$

Ayub adalah contoh nyata, seorang yang sungguh-sungguh beriman namun tak lepas dari penderitaan. Seperti yang dikemukakan Bartolomeus Wahyu Kurniadi, Ayub belajar menerima dan menanggapi penderitaannya dengan sikap iman. Dengan sikap iman itu Ayub hanya mengarahkan hati dan pikiran kepada kedaulatan dan kehendak Allah. Itu sebabnya sikap Ayub ini dapat menjadi salah satu inspirasi bagi orang percaya sekarang, untuk tetap beriman kepada Allah walau dalam situasi yang sangat menderita sekalipun. $^{3} \quad$ Seperti yang

\footnotetext{
${ }^{2}$ Elvin Atmaja Hidayat, "Iman Di Tengah Penderitaan: Suatu Inspirasi Teologis-Biblis Kristiani," MELINTAS 32, no. 3 (September 6, 2017): 285, accessed April 5, 2019, http://journal.unpar.ac.id/index.php/melintas/article/ view/2695.

${ }^{3}$ Bartholomeus Wahyu Kurniadi, "Inspirasi Kisah Ayub Bagi Seorang Katolik Dalam Menghadapi
}

diungkapkan Ayub, "Karena Ia tahu jalan hidupku; seandainya Ia menguji aku, aku akan timbul seperti emas" (Ayub 23:10). Terbukti, Ayub melalui penderitaannya itu, ia menjadi semakin mengenal Allah (Ayub $42: 5)$.

Ada pun yang melatarbelakangi seluruh rangkaian kisah Ayub secara umum adalah kesadaran akan Allah. Kitab Ayub ini mempersoalkan penderitaan pribadi, bukan penderitaan suatu bangsa, yaitu mengenai kedaulatan Allah mengizinkan orang beriman, orang tidak bersalah mengalami penderitaan, dan kerelaan untuk menerimanya tanpa kehilangan imannya. Melalui narasi kitab Ayub ini menceritakan atau menggambarkan pengalaman manusia secara universal untuk menguatkan percaya masa kini yang sedang menghadapi penderitaan.

Kitab Ayub merupakan salah satu kanon Ibrani yang unik karena kisahnya yang sangat ekstrim dan tidak diketahui siapa penulisnya. Sekalipun demikian, kitab ini diakui sebagai sebuah karya sastra bernilai tinggi yang menceritakan bagaimana kesadaran manusia akan karya Allah di dalam dunia, khususnya

Penderitaan," MELINTAS 31, no. 1 (July 22, 2015): 47, accessed April 5, 2019, http://journal.unpar.ac.id/index.php/melintas/article/ view/1455. 
menghadapi persoalan hidup. Oleh kaum Ibrani kitab Ayub dipercaya sebagai sebuah hagiographa. ${ }^{4}$

Cara Ayub merespon penderitaan yang dialaminya menunjukkan sikap seorang yang memiliki kesadaran yang tinggi akan Allah. John Drane menjelaskan bagian kisah ini menggambarkan Allah sebagai pemimpin sidang Ilahi, dan menerangkan penderitaan Ayub dengan referensi pada tuduhan yang dijatuhkan atas Ayub oleh si pendakwa (iblis). Tuduhannya ialah bahwa Ayub saleh hanya karena ia tahu bahwa kesalehan itu berpahala. ${ }^{5}$ Ucapan istri Ayub dan temantemannya juga menegaskan adanya konsep teologi yang dibangun atas dasar kesadaran mereka tentang Allah sesuai konteks waktu itu. Kesalehan diberi pahala dengan kemakmuran dan kebahagiaan, sedangkan kefasikan diberi penghukuman. Paham ini disebut retribusi. Retribusi adalah sebuah pemahaman bahwa Allah itu adil akan mengganjar seseorang sesuai perbuatannya, yakni memberkati orang benar dan menghukum orang fasik; siapa yang taat kepada-Nya akan diberkati dan siapa yang tidak taat akan dihukum atau

\footnotetext{
${ }^{4}$ Hagiographa berasal dari dua kata yaitu hagio atau hagios artinya kudus, dan grapha atau graphe artinya tulisan. Jadi hagiographa adalah tulisan kudus.

5 John Drane, Memahami Perjanjian Lama 1 (Jakarta: Persekutuan Pembaca Alkitab, 2009), 88.
}

tidak akan diberkati. Manusia patut mendapat apa yang patut diterimanya menurut penilaian Tuhan. Prinsip ini disebut retribusi. Prinsip retribusi ini dalam arti sempit sama dengan sebagai balas jasa atau "ganti rugi". Inilah pola tradisional pada waktu itu.

Pemahaman retribusi ini menjadi pemikiran umum yang melatarbelakangi sikap mereka terhadap realitas kesadaran akan Allah dan kehadiran-Nya di dalan kehidupan mereka. Larosa menyatakan, bahwa pada zaman di mana penulis Kitab Ayub hidup, umat Israel menghadapi persoalan yang cukup rumit. Mereka melihat dalam kehidupan sehari-hari suatu kenyataan yang sangat kontradiktif. Orangorang saleh menderita, sementara orangorang fasik, orang-orang berdosa dapat menikmati hidup yang lebih enak. Pandangan tradisional yang biasa disebut ortodoks atau teodisi ini ternyata tidak dapat menjelaskan persoalan tersebut dengan cukup memuaskan. Menurut pandangan teodisi, orang saleh pasti diberkati Allah dan orang jahat pasti dihukum. ${ }^{6}$ Maka konsekuensinya ialah mereka (Bildad, Elifas, dan Zofar) selalu memandang orang yang menderita sebagai orang yang telah melakukan dosa. Menurut

\footnotetext{
${ }^{6}$ Arliyanus Larosa, Belajar Dari Kitab Ayub: Tegar Dalam Penderitaan (Bandung: Kalam Hidup, 1997), 10 .
} 
logika teologi teodisi mereka (Bildad, Elifas, dan Zofar), diperoleh konklusi bahwa Ayub bersalah/berdosa. Ayub tetap teguh dalam pendiriannya bahwa ia mengklaim dirinya tidak melakukan sesuatu yang jahat di hadapan Allah (psl. 1:1). Ayub tidak puas dengan penjelasan ortodoks ini. Ayub mengajukan pertanyaan-pertanyaan kritis terhadap pandangan ortodoks atau retribusi tersebut. Hal ini menyebabkan sebuah rekonstruksi perspektif klasik itu.

Kitab Ayub ditulis dengan maksud untuk meruntuhkan paham tradisional tersebut. ${ }^{7}$ Ayub di dalam Kitab Ayub ini adalah tokoh yang menggambarkan sikap protes terhadap pandangan/teologi tradisional tersebut (teodisi). Emanuel da Santo Meo Djogo, menguraikan secara keseluruhan kitab Ayub adalah mengisahkan seorang saleh (1:1) yang ditimpa kemalangan $(1: 13-19 ; 2: 7-8)$ dan mempertanyakannya kepada Allah, lewat berbagai dialog yang diutarakan bersama ketiga temannya, yang kemudian juga mendapat tanggapan dari Elihu (4:137:24). Pembicaraan mereka berkisar persoalan mengenai musibah penderitaan

\footnotetext{
${ }^{7}$ Emanuel Djogo, “Tinjauan Permasalahan Teodise Kitab Ayub Dan Relevansinya Terhadap Penderita HIV/AIDS," MELINTAS 33, no. 3 (2017): 342369, accessed April 5, 2019, http://journal.unpar.ac.id/index.php/melintas/article/ view/3076.
}

yang dialami Ayub, orang saleh (1:12:13). ${ }^{8} \quad$ Percakapan pun berkembang menjadi debat. ${ }^{9}$ Yang seorang berbicara tanpa menghiraukan pembicaraan pihak lain.

$$
\text { Pandangan/teologi tradisional }
$$

teodisi inilah yang menjadi dinamika kesadaran akan Allah dalam kasus apa yang dialami Ayub sebagai orang yang saleh (seharusnya sesuai dengan logika teodisi atau retribusi, Ayub tidak mengalami petaka, tapi diberkati). Kesadaran Ayub akan Allah sedang dibentuk melalui penderitaan yang dialaminya. Biasanya Allah memberkati orang saleh yang mengasihi-Nya. Allah juga menghakimi orang yang fasik dan jahat, secara umum memang benar. Tetapi, tidak selalu terjadi demikian. Tidaklah benar untuk menerapkan pendapat itu kepada Ayub.

Persoalan yang dihadapi Ayub mengantar kita untuk menemukan kesadaran akan Allah yang paling hakiki dalam hidup manusia sepanjang jaman. Kisah Ayub bukan sekadar kisah biasa tetapi menjadi sebuah kisah yang "hidup" tentang seorang yang saleh, takut akan

\footnotetext{
${ }^{8}$ Larosa, Belajar Dari Kitab Ayub: Tegar Dalam Penderitaan, 344.

9 Ada tiga babak debat. Pertama: Ayub, Elifas, Bildad dan Zofar (4:1-14:22), kedua: Ayub, Elifas, Bildad dan Zofar (15:1-21:34), ketiga: Ayub, Elifas, Bildad dan Zofar (22:1-27:23).
} 
Allah, jujur dan menjauhi kejahatan tetapi kehilangan semua yang dimilikinya karena imannya kepada Allah.

Ayub mengalami pergumulan hidup, bermula dari ketaatan (prolog), berubah menjadi dialog, dan juga dipertajam melalui konflik pribadi dan berakhir dalam ketaatan yang lebih tinggi sesudah mendengar jawaban-jawaban Allah. Kitab Ayub sesungguhnya mayoritas mengandung konflik pribadi Ayub dalam memandang penderitaan tak terjelaskan yang dialaminya kepada Tuhan. Melalui kejadian atau penderitaan tersebut, kesadaran akan Allah justru makin meningkat. Sebab iman bukanlah sesuatu yang statis, tapi dinamis di dalam hubungan antara manusia (orang beriman) engan Allah. Allah mengizinkan Ayub orang yang saleh mengalami penderitaan, dan kerelaan untuk menerimanya tanpa kehilangan imannya. Dengan demikianlah terbentuk kesadaran akan akan Allah melalui pengalaman konkrit (di dalam penderitaan).

Artikel ini bertujuan untuk membangun kesadaran akan Allah dalam rangka menolong orang Kristen pada saat mengalami penderitaan dalam hidupnya dengan berkaca kepada sikap Ayub dalam penderitaan. Ayub menjadi prototype mengenai seorang beriman yang mengalami problematika kehidupan yang tidak dapat dijelaskan tetapi justru pada akhirnya membawa kepada tingkat kesadaran akan Allah serta membawa Ayub kepada pengenalan akan Allah yang lebih mendalam,"Hanya dari kata orang saja aku mendengar tentang Engkau, tetapi sekarang mataku sendiri memandang Engkau”(42:5). Ketika Ayub kehilangan harta dan semua anak-anaknya mati, maka Ayub tetap tekun di dalam kesalehannnya di hadapan Allah. Ayub tetap tekun dalam kesalehannya, bukan karena harta bendanya, melainkan karena kesadaran akan Allah yang dimilikinya.

\section{METODE PENELITIAN}

\section{Kritik Naratif}

Metode yang digunakan dalam kajian konseptual Ayub 1-2 adalah metode analisis naratif. Metode analisis naratif atau kritik naratif adalah suatu metode analisis Alkitab yang memusatkan perhatian hanya pada teks dan tidak terlalu menaruh perhatian pada hal-hal yang di luar teks, seperti misalnya aspek historis dari teks tersebut. ${ }^{10}$ Dalam kritik naratif ada dua aspek, yaitu kisah dan

\footnotetext{
${ }^{10}$ P. A. Didi Tarmedi, “Analisis Naratif: Sebuah Metode Kristiani Hermeneutika Kitab Suci," MELINTAS 29, no. 3 (July 14, 2014): 331-360, accessed February 25, 2018, http://journal.unpar.ac.id/index.php/melintas/article/ view/902/889.
} 
pengkisahan. Kisah adalah merupakan peristiwa atau pengalaman yang tertulis dalam teks tersebut, sedangkan pengkisahan adalah pemaknaan dari kisah tersebut. Kisah dapat sama, namun pengkisahan dapat berbeda-beda satu dengan yang lainnya. Oleh sebab itu, dalam kritik naratif, dikenal adanya narator. Narator adalah seorang tokoh imajiner yang diciptakan oleh penulis, yang perannya sangat dominan tampil sebagai orang yang maha tahu. Seorang narator berusaha untuk mempengaruhi pembaca melalui penyampaian kisahnya, yang dikenal sebagai sudut pandang atau ideologi dari narator.

Kajian dalam artikel ini akan menarasikan kisah Ayub sebagaimana yang terdapat dalam teks Ayub 1-2 untuk kemudian menghasilkan pemaknaan atas kisah tersebut dalam konteks penderitaan orang percaya. Narasi tulisan ini terdiri atas dua bagian, yaitu narasi 1:1-22 yang menceritakan tentang seorang tokoh bernama Ayub yang terkaya di sebelah timur di tanah Us dan proses penderitaannya yang pertama, dan narasi 2:1-13 yang menceritakan proses penderitaan Ayub yang kedua.

Kitab Ayub
Para ahli Perjanjian Lama menggolongkan kitab Ayub ini ke dalam jenis sastra "hikmat" (sama seperti Kitab Amsal dan Pengkhotbah). Kitab Ayub sering disebut sebagai cerita berbingkai. ${ }^{11}$ Inti kitab Ayub (3-42:6) dibungkus oleh apa yang biasa disebut oleh para ahli Perjanjian Lama sebagai prolog (pasal 1 dan 2) dan epilog (42:7-17). Prolog dan epilog inilah yang biasa disebut sebagai bingkai cerita kitab Ayub. ${ }^{12}$ Menurut David Atkinson, struktur Kitab Ayub dibagi menjadi tiga bagian. Pertama (pasal 1-2) prolog berbentuk prosa, menggambarkan latar belakang peristiwa Ayub. Dalam prolog itu realitas sorgawi dan realitas di bumi serentak dituturkan. Kedua (pasal 3:1-42:6) dalam bentuk sajak yang panjang, menceritakan bagaimana Ayub dan sahabat-sahabatnya berdebat untuk mengerti keadaan Ayub, dan pada akhirnya Ayub mengindahkan suara Allah. Ketiga (pasal 42:7-14) epilog juga dalam bentuk prosa, mengakhiri cerita peristiwa Ayub dengan happy ending. ${ }^{13} \quad$ Kitab Ayub masuk kategori kitab puisi atau syair. David Cline menyatakan bahwa kerangka kitab Ayub adalah prosa, tetapi intinya

\footnotetext{
${ }^{11}$ Temper Longman III, Job (Grand Rapids: Baker Academic, 2012), 29-30.

${ }^{12}$ Larosa, Belajar Dari Kitab Ayub: Tegar Dalam Penderitaan, 9.

${ }^{13}$ David Atkinson, Ayub (Jakarta: Yayasan Komunikasi Bina Kasih/OMF, n.d.), 15.
} 
adalah puisi. ${ }^{14}$ Karena bentuknya bersifat puisi, kita wajib menguraikan sesuai dengannya. Di dalam kitab Ayub terdapat beberapa jenis sastra. Kitab ini berasal dari tradisi hikmat. ${ }^{15}$ Dialog terjadi dengan latar belakang Siria atau Edom sebagai tempat asal Elifaz dan Ayub. Tempat-tempat lain yang disebutkan sebagai para penyerang Ayub adalah daerah Sabia, Kaldea, Teman, Syeba. Puisi-puisi mengekspresikan pengetahuan tentang topik-topik yang bervariasi. Sebagai contoh adalah kisah tentang penglihatan wahyu ilahi (4:12-16), konstelasi bintang $(9: 9 ; 38: 3)$, prototype manusia ideal (15:7-9), logam mulia (22:21-25; 28:1-2), permata berharga (28:16-19), pertambangan (28:1-11), dan gambaran tentang binatang (38:39-39:30).

Bentuk kisah Ayub memiliki kerangka utama berupa didactive narative, sebuah narasi yang dimaksud untuk mendidik para pendengarnya. Baik prolog maupun epilog (yang bersifat naratif, bukan puisi, yaitu pasal 1-2 dan pasal 42:7-

\footnotetext{
${ }^{14}$ W.S. Lasor, D.A. Hubbrad, and F.W. Bush, Pengantar Perjanjian Lama (Jakarta: BPK Gunung Mulia, 2015), 40.

15 Tradisi hikmat yang dimaksud adalah pengungkapan kisah yang berasal dari wilayah timut dekat dengan pengaruh kuat dari teks Mesopotamia dan Mesir. Kisah Ayub menggambarkan bagaimana orang pada masa itu memahami Allah dan cara kerjanya dalam hidup manusia.
}

17) merupakan narasi bersifat didaktif. ${ }^{16}$ Pasal 3-42 jelas core-nya adalah puisi (kendati pun berbentuk puisi tetapi memiliki karakter didaktif juga). Hassel Bullock menyatakan kitab Ayub ini bersifat didaktif dalam arti bahwa sang pengarang berusaha mengajarkan kebenaran agamawi; suatu tugas yang dilaksanakannya terutama dengan memakai sarana puisi lirik yang mengungkapkan perasaan-perasaan yang dalam. ${ }^{17}$ Di dalamnya mendeskripsikan bagaimana cara Ayub meresponi penderitaannya. Narasi ini ingin mendidik para pendengar atau pembacanya mengenai cara mereka sendiri bertahan dalam penderitaan mereka sendiri. Para pembaca diperlihatkan kisah Ayub sebagai salah satu contoh seorang yang saleh tetapi mengalami hal yang sangat ekstrim: Ayub seorang yang kaya raya, dan mengalami kemiskinan yang sangat ekstrim; ia seorang yang terhormat sekaligus terhina; ia seorang yang terkenal kesalehannya dan keberaniannya menghadap Tuhan. Ayub mengalami Tuhan yang membisu dan Tuhan yang berbicara panjang lebar.

\footnotetext{
${ }^{16}$ Kitab Ayub itu bersifat didaktif dalam arti bahwa sang penulis kitab ini berusaha mengajarkan kebenaran agamawi dengan memakai sarana puisi lirik yang mengungkapkan perasaan-perasaan yang dalam.

${ }^{17}$ C. Hassell Bullock, Kitab-Kitab Puisi Dalam Perjanjian Lama (Malang: Gandum Mas, 2003), 97.
} 
Jawaban Tuhan dalam Kitab Ayub adalah terpanjang di dalam Perjanjian Lama. Iman Ayub juga ekstrim, dimana awalnya ia adalah seorang yang berserah diri/menerima keadaannya, kemudian berubah menjadi protes terhadap hari kelahirannya dan memprotes Tuhan hingga mengakui kedaulatan-Nya.

Jenis sastra kedua adalah individual lament (keluhan pribadi) dan lawsuit (perkara hukum, penuntutan perkara) di dalam pasal 3 dan pasal 29-31. Jenis sastra individual lament terhadap Tuhan juga muncul dalam sastra para nabi (Yer.20) dan Kitab Mazmur (44 dan 88). Tiga karakteristik utama dalam kisah Ayub adalah pembicara, Tuhan, dan pembelaan. Kitab Ayub disusun dalam sebuah dialog dramatis mengenai keluhan Ayub. William Dyrness menyatakan bahwa sastra ini sebenarnya justru menunjukkan sebuah intimacy dengan Tuhan yang sangat rohani dan personal. Manusia berani membuka diri terhadap Tuhan, bahkan sampai mengeluh soal luka jiwanya. Kitab yang berisi sikap protes terhadap Tuhan ini diterima oleh kanon Alkitab sebagai jenis sastra yang legitimate dan juga sebagai spiritualas yang legitimate. ${ }^{18}$

${ }^{18}$ William Dyrness, Tema-Tema Dalam Teologi Perjanjian Lama (Malang: Gandum Mas, 1992), 30.
Jenis sastra yang terakhir adalah disputation speech (debat hikmat). Semua dialog antara Ayub dan teman-temannya (pasal 4-27) dan antara Ayub dan Tuhan (38:1-42:6) termasuk kategori jenis sastra disputation speech. ${ }^{19}$ Tokoh di dalam kitab Ayub memerankan dirinya sebagai guru hikmat dalam sebuah debat yang tajam, saling menyalahkan dan memojokkan menurut keyakinan masing-masing, untuk membuktikan kebenaran perspektif hikmat mereka sendiri. Secara literer, jawaban Ayub lebih luas dan panjang daripada jawaban teman-temannya. Dan jawaban Tuhan lebih luas dan panjang daripada jawaban Ayub. Secara literer pula, dapat diketahui mengenai siapa yang dianggap paling benar di dalam setiap debat itu, yakni yang paling panjang jawabannya karena dibangun atas dasar yang lebih lengkap. Setiap tokoh memaparkan perspektif mereka mengenai kesadaran akan Allah untuk menjawab persoalan yang dihadapi oleh Ayub.

\section{HASIL DAN PEMBAHASAN}

\section{Narasi : Ayub dan Penderitaannya yang Pertama (1:1-22)}

Dalam bagian ini terdiri atas tiga bagian, yakni narasi 1:1-5 yang menceritakan tentang seorang tokoh

\footnotetext{
${ }^{19}$ Longman III, Job, 31-32.
} 
bernama Ayub yang saleh, takut akan Allah, seorang ayah dari tujuh anak lakilaki dan tiga anak perempuan, dan juga seorang yang kaya raya serta termasyur di zamannya, bagia kedua adalah narasi 1:619 yang menceritakan proses penderitaannya yang pertama, ketiga adalah narasi 2:1-13 yang menceritakan proses penderitaan Ayub yang kedua.

\section{1:1-5 Sosok Ayub}

Ayub adalah seorang yang saleh dan jujur, takut akan Allah dan menjauhi kejahatan. Ayub taat dan setia beribadah kepada Allah, serta bermoral baik $(1: 1,8$; 2:3). Ayah dari tujuh anak laki-laki dan tiga anak perempuan (1:2). Di sini, penting kita perhatikan bahwa Allah sendirilah yang menyatakan Ayub sebagai seorang yang saleh dan jujur, takut akan Allah dan menjauhi kejahatan $(1: 1,8 ; 2: 3)$. Alden A. Gannett menjelaskan pengertian saleh dalam ayat ini dimaksudkan seorang yang hidup rohaninya tidak bercela. ${ }^{20}$

Ayub juga ditampilkan sebagai "Sang Konglomerat" pada zamannya. "Ia memiliki tujuh ribu kambing domba, tiga ribu unta, lima ratus pasang lembu, lima ratus keledai betina dan budak-budak dalam jumlah yang sangat besar" (1:3). Di

${ }^{20}$ Alden A. Gannett, Pengertian Tentang Sakit Dan Penderitaan Dari Kitab Ayub (Jepara: Silas Press, n.d.), 2. antara bangsa-bangsa lain pun ia terkenal sebagai orang yang dermawan, berbudi, dan sangat dihormati serta orang yang terbesar pada masa itu (1:3). Penting diketahui bahwa menurut kebudayaan Ibrani, kemakmuran biasanya dianggap pertanda atau simbol dari berkat Allah. Di dalam Kitab Ulangan 28, jelas hal itu dengan membandingkan berkat-berkat yang akan diberikan kepada orang yang menaati Allah, dan berbagai kutuk akibat ketidaktaatan. Kemakmuran dan kebahagiaan kadang-kadang dipakai Allah sebagai tanda nyata dari berkat-Nya. ${ }^{21}$

Kualitas hidup rohani Ayub sebagaimana disebut di dalam Kitab Ayub bahwa ia adalah seorang yang saleh dan jujur; takut akan Allah dan menjauhi kejahatan. Dan bahwa kekayaan/kemakmuran bukanlah yang menyebabkan/menjadi dasar Ayub memiliki kualitas rohani yang tinggi, melainkan lebih kepada pengalaman religiusnya atau kesadaran akan Allahhubungan pribadi dengan Allah. Perilaku Ayub di dalam menghadapi kesulitan hidup sekalipun segala hartanya bahkan semua anak-anaknya mati, selalu dikendalikan oleh kesadaran akan Allah

\footnotetext{
${ }^{21}$ Atkinson, Ayub, 19-20.
} 
yang tinggi. Dengan kata lain, kesadaran Ayub itu selalu dikaitkan dengan Allah.

Ayub juga seorang yang senantiasa berdoa bagi keluarganya (1:4-5). Dalam ayat-ayat ini jelas menyatakan bahwa betapa salehnya Ayub dan seorang ayah yang senantiasa berdoa bagi keluarganya. Setiap kali, apabila hari-hari pesta anakanaknya berlalu, Ayub memanggil mereka, dan menguduskan mereka; keesokan harinya, pagi-pagi, bangunlah Ayub, lalu mempersembahkan korban bakaran sebanyak jumlah mereka sekali, sebab pikirnya, mungkin anak-anaknya sudah berbuat dosa dan telah mengutuki Allah di dalam hati mereka. Demikianlah dilakukan Ayub senantiasa.

Sebagai imam keluarga, Ayub mempersembahkan korban bakaran untuk anak-anak mereka. Ia senantiasa berdoa bagi keluarga dan berusaha menjaga kekudusan keluarganya. Ayub mengerti bahwa mengutuki Allah adalah dosa, dan ia ingin agar seluruh keluarganya tetap bersih dari dosa. Jadi pagi-pagi sekali (ungkapan Ibrani yang berarti rajin dan teratur), Ayub bangun dan mempersembahkan korban bakaran untuk mereka semua. Hal itu Ayub lakukan sepanjang hidupnya-senantiasa $(1: 5){ }^{22}$ Dampak kesadaran Ayub akan Allah nampak dari caranya menguduskan anakanaknya:

Setiap kali, apabila hari-hari pesta telah berlalu, Ayub memanggil mereka, dan menguduskan mereka; keesokan harinya, pagi-pagi bangunlah Ayub, lalu mempersembahkan korban bakaran sebanyak jumlah mereka sekalian, sebab pikirnya: 'Mungkin anakanakku sudah berbuat dosa dan telah mengutuki Allah di dalam hati.' Demikianlah dilakukan Ayub senantiasa" $(1: 15)$.

\section{1:6-19 Penderitaan Ayub yang pertama}

Kita mengakui bahwa kisah percakapan Allah dan Iblis sebagaimana diuraikan dalam Kitab Ayub pasal 1 dan 2, itu sungguh-sungguh terjadi karena itu berasal dari penyataan Allah sendiri. Tidak ada kemungkinan lain: kebenaran Kitab Ayub diakui atau tidak. Jika kisah itu berasal dari penyataan Allah, tentulah percakapan tersebut terjadi sungguhsungguh walaupun cara menuturkan/menceritakannya adalah antropotatis, artinya: perbuatan Allah dilukiskan dengan memakai kata-kata dan perbuatan manusia, agar dapat dipahami oleh akal manusia. Allah di sorga seringkali menyatakan diri-Nya kepada kita dengan antropomorpisme yang sama: Allah duduk di atas takhta, Allah menyesal, tangan Allah, mata Tuhan, langkah kaki Tuhan, dan sebagainya.

\footnotetext{
${ }^{22}$ Ibid, 20-21.
} 
"Pada suatu hari datanglah anak-anak Allah $^{23}$ menghadap Tuhan dan di antara mereka datanglah juga Iblis" (1:6). ${ }^{24}$

Kita perhatikan di sini bahwa yang membuka jalan kepada penderitaan Ayub adalah Allah sendiri: "Maka bertanyalah Tuhan kepada Iblis: 'Dari mana engkau?' Lalu jawab Iblis kepada Tuhan: "Dari perjalanan mengelilingi dan menjelajah bumi" (1:7). "Lalu bertanyalah Tuhan kepada Iblis: Apakah engkau memperhatkkan hamba-Ku Ayub? Sebab tiada seorang pun di bumi seperti dia, yang demikian saleh dan jujur, yang takut akan Allah dan menjauhi kejahatan" (1:8). Jelas inisiatif ini datang dari pihak Tuhan. Allah yang membuka pembicaraan tentang Ayub. Dalam ayat ke 9, Iblis menjawab: "Apakah dengan tidak mendapat apa-apa Ayub takut akan Allah?" Dengan kata lain, Iblis mau mengatakan: "Ah, ia hanya beribadah kepada-Mu karena ia mengharapkan berkat-berkat dari pada-

\footnotetext{
${ }^{23}$ Ada banyak tafsiran mengenai anak-anak Allah dalam teks ini, tapi menurut kebanyak para ahli Alkitab, yaitu bahwa anak-anak Allah itu adalah malaikat.

${ }^{24}$ Kisah serupa dapat kita jumpai dalam Wahyu 12:10 diceritakan, bahwa Iblis menghadap ke hadirat Tuhan sebagai "pendakwa saudara-saudara kita"; dan di dalam Zakharia 3:1-2 diceritakan juga, bahwa Iblis "berdiri" di hadapan hadirat Allah. Ada banyak ayat yang menerangkan, bahwa Iblis diizinkan oleh Allah mencobai umat-Nya (Luk.22:31-32; 1 Kor.5:5; 1 Tim.1:20; 2 Tim.2:26), tentunya dengan kuasa yang terbatas (berada dalam kendali-Nya). Setiap izin Tuhan itu selalu disertai suatu batas tertentu. Iblis tidak dapat bertindak di luar apa yang diizinkan oleh Allah.
}

Mu." Iblis mendakwa Ayub melayani Allah, takut akan Allah dan beribadah kepada Allah hanya karena demi kemakmuran yang akan Ayub terima. Iblis sibuk mencari-cari kesalahan Ayub dengan tujuan menghancurkan. Hal ini sangat Nampak dalam cara Iblis menjawab Allah,"Apakah Allah berpendapat kesalehan Ayub tanpa pamrih? Tidakkah tahu Allah bahwa Ayub mengharapkan imbalan dari semuanya itu? Lagi pula, karena Allah membentengi dia dengan kekayaan yang melimpah dan dukungan keluarga. "Bukankah Engkau yang membuat pagar sekeliling dia dan rumahnya serta segala yang dimilikinya? Apa yang dikerjakannya telah Kau berkati dan apa yang dimilikinya makin bertambah di negeri itu" (1:10-11). Itulah dakwaan Iblis. Dan pertanyaan Iblis adalah salah satu tema utama Kitab Ayub: Apakah dengan tidak mendapat apa-apa Ayub takut akan Allah? (1:9).

Iblis mengetahui bahwa Allah telah memasang "pagar pelindung" di sekitar Ayub. Dalam ayat 11, Iblis melemparkan tantangan: "Tetapi ulurkanlah tangan-Mu dan jamahlah segala yang dipunyainya, ia pasti mengutuki Engkau di hadapan-Mu." Seakan-akan Iblis mengatakan kepadaNya: Allah, Engkau terlalu yakin tentang Ayub ini. Ia hanya mau takut akan Engkau 
karena materi yang Kau limpahkan kepadanya. Dan Allah menjawab: "Nah, segala yang dipunyainya ada dalam kuasamu, hanya janganlah engkau mengulurkan tanganmu terhadap dirinya" (ayat 12). Di sini nyata bahwa Allah yang memberikan izin kepada Iblis untuk mencobai Ayub, yaitu atas segala yang dimiliki Ayub, tetapi tidak atas diri Ayub sendiri.

Tentang semua percakapan/dialog antara Allah dengan Iblis, Ayub sendiri sama sekali tidak tahu. Hal serupa dikatakan Arliyanus Larosa bahwa Ayub tidak mengetahui hal itu. Ayub sendiri tidak diberi tahu oleh Allah. Justru ketidaktahuan Ayub sama sekali tentang apa kaitan penderitannya di bumi dengan kebijaksanaan di sorga, membuat peristiwa itu sangat berbobot. $^{25}$ Baxter menyatakan demikian:

Sesungguhnya Ayub tidak dimaksudkan untuk mengetahui keterangan yang menyebabkan ia menanggung derita; dan justru pada kenyataan bahwa ia tidak mengetahuinya itulah tergantung segala sesuatu dalam pencobaan yang berlangsung atas dirinya. Jika Ayub sudah mengetahuinya, tentulah tidak ada tempat lagi bagi iman; dan ia tidak

\footnotetext{
${ }^{25}$ Larosa, Belajar Dari Kitab Ayub: Tegar Dalam
} Penderitaan, 21. akan keluar dari api pencobaan sebagai emas yang teruji. ${ }^{26}$

Di sini tampak hubungan yang indah antara kekuasaan Allah dan pertanggung jawaban makhluk ciptaanNya. Allah tidak mendikte apa yang harus Iblis lakukan, tapi Allah tetap memegang kendali (berdaulat), sehingga Iblis tidak bisa bertindak melampaui batas tersebut. David Atkinson berkata: memang Allah yang mengizinkan Iblis mencobai Ayub, namun Allah menentukan batas pencobaan itu. Iblis selamanya di bawah kuasa dan pengendalian Allah $(1: 12){ }^{27}$ J. Sidlow Baxter mengatakan bahwa setiap izin Tuhan itu selalu disertai suatu batas yang tertentu. Pembatasan itu merupakan suatu penghiburan bagi orang percaya: Iblis tidak dapat berbuat sekehendak hatinya, tidak dapat bertindak di luar apa yang diizinkan oleh Allah - sama halnya dengan kuasa Pilatus terhadap Yesus (Yoh.19:11). ${ }^{28}$

Ayub, seorang konglomerat, kehilangan segala-galanya dalam satu hari. Ayub kehilangan kesepuluh anaknya dalam satu hari saja. Mereka berkumpul di rumah saudara sulung mereka. Tiba-tiba bencana angina rebut bertiup dari

\footnotetext{
${ }^{26}$ J. Sidlow Baxter, Menggali Isi Alkitab 2: Ayub s/d Maleakhi (Jakarta: Yayasan Komunikasi Bina Kasih, 1989), 17.

27 Atkinson, Ayub, 24-25.

${ }^{28}$ Baxter, Menggali Isi Alkitab 2: Ayub s/d Maleakhi, 29.
} 
seberang pada gurun. Rumah itu dilandanya pada empat penjurunya dan roboh menimpa mereka, sehingga mereka mati. Penting diperhatikan bahwa Ayub baru saja mempersembahkan korban bakaran demi semua anak-anaknya. Itu berarti sama sekali tidak ada lagi dosa yang tersembunyi yang mencemari Ayub maupun keluarganya. Mereka baru saja ditahirkan. Memang Ayub dan keluarganya adalah pendosa, tapi Ayub benar-benar saleh di hadapan Allah. Allah yang sendirilah yang mengatakan Ayub saleh. Tidak ada suatu apa pun yang mengganjanl persekutuan antara Allah dan Ayub, juga antara Allah dan keluarga Ayub. Korban bakaran telah dipersembahkan. $^{29}$

Kendati pun diri Ayub dan keluarganya demikian saleh, toh empat bencana menimpa Ayub. Beruntun empat pesuruh melapor kepada Ayub (1:14-19) sebagai berikut:

"Orang-orang Syeba menyerang dan merampas ... dengan mata pedang. Hanya aku yang luput, sehingga dapat memberitahukan hal itu kepada tuan."

“Api ... membakar serta memakan habis kambing domba dan penjagapenjaga. Hanya aku yang luput, sehingga dapat memberitahukan hal itu kepada tuan."

“Orang-orang Kasdim ... menyerbu unta-unta dan merampasnya serta membunuh penjaganya dengan mata pedang. Hanya aku yang luput, sehingga dapat memberitahukan hal itu kepada tuan."

"Angin ribut melanda rumah tempat anak-anak tuan berpesta ... semua anak tuan mati. Hanya aku yang luput, sehingga dapat memberitahukan hal itu kepada tuan."

\section{1:20-22 Reaksi Ayub}

Betapa mengejutkan berita itu (1:14-19). Bagaimana respon Ayub? Di dalam ayat 20-22: "Berdirilah Ayub, lalu mengoyak jubahnya, dan mencukur kepalanya, kemudian sujudlah ia dan menyembah, katanya: "Dengan telanjang aku keluar dari kandungan ibuku, dengan telanjang juga aku akan kembali ke dalamnya. Tuhan yang memberi, Tuhan yang mengambil, terpujilah Tuhan!" Dalam semuanya itu Ayub tidak berbuat dosa dan tidak menuduh Allah berbuat yang kurang patut."

Reaksi Ayub yang pertama adalah tertuju pada Allah-ia sujud menyembah. Terbukti Ayub tidak mengutuki Allah. Dan

\footnotetext{
${ }^{29}$ Atkinson, Ayub, 25.
} 
itu juga membuktikan Iblis total salah. Ayub mengakui kedaulatan Allah yang memberi dan mengambil, sehingga ia menerimanya tanpa menuduh Allah berbuat yang kurang patut. Ayub melakukan refleksi diri untuk merenungkan masalahnya dengan berdiam diri selama tujuh hari lamanya tanpa sepatah katapun. Kedua, Ayub menyatakan kesadarannya akan segala keberadaan materi adalah dari pemberian Tuhan. Tuhanlah yang memberi segala yang dia miliki baik semua harta maupun keluarganya. Keyakinan itulah yang membuat Ayub menjadi sadar, bahwa tidak ada hak yang dimilikinya untuk mempertahankan semuanya itu. Untuk menegaskan hal itu, Ayub memberikan pernyataan kedua, Tuhan yang memberi, Tuhan yang mengambil. Hal tersebut dapat disimpulkan bahwa Tuhanlah yang memiliki hak untuk mengambil kembali apa yang pernah diberikan kepada Ayub, dengan banyak cara. Perenungan diri Ayub menunjukkan kesadarannya akan Allah dan wujud penerimaannya terhadap kedaulatan Tuhan-Ia sempurna.

Ayat 22 dikatakan, "Dalam kesemuanya itu Ayub tidak berbuat dosa dan tidak menuduh Allah berbuat yang kurang patut". Pengertian "tidak berdosa" maksudnya bahwa selama dalam kondisinya yang sulit, Ayub tidak pernah melakukan yang hal tidak benar dalam arti mengutuki Allah. Ayat ini jelas menunjukkan bahwa Ayub sadar apa yang ia alami masih bertalian dengan rencana Allah, dan ia tetap berkeyakinan bahwa Allah tidak melakukan hal yang kurang patut. Itu merupakan bukti Ayub memiliki kesadaran yang tinggi akan Allah.

Ayub dan Penderitaannya yang Kedua (2:1-13)

\section{2:1-8 Penderitaan Ayub yang kedua}

Peristiwa dalam percakapan pasal 2:1-6 serupa dengan peristiwa dalam pasal 1:1-12, namun ada perbedaan dalam tiga hal. Pertama, Iblis datang bersama anakanak Allah dengan tujuan menghadap Tuhan (2:1). Apakah Iblis datang untuk mengakui bahwa Allah menang dalam putaran pertama, lalu berpura-pura memberi hormat kepada-Nya? Kedua, Allah memberi keterangan tambahan tentang Ayub,"ia tetap dalam kesalehannya (2:3), yang menekankan bahwa Ayub benar-benar saleh. Ketiga, Allah menambahkan,"engkau telah membujuk Aku melawan dia untuk mencelakakannya tanpa alasan” (2:3). Dalam ungkapan itu tersirat pernyataan Allah bahwa Iblis 
gagal. Dakwaan Iblis tentang kesalehan Ayub meleset sama sekali. ${ }^{30}$

Tuhan memuji kesalehan Ayub, setelah ia menjadi miskin dalam sehari dan kehilangan kesepuluh anaknya sekaligus (2:3). Iblis masih belum melepaskan cengkeramannya atas Ayub. Lalu jawab Iblis kepada Tuhan: "Kulit ganti kulit! (2:4). Kemudian Iblis membujuk Tuhan,"Tetapi ulurkanlah tangan-Mu dan jamahlah tulang dan dagingnya, ia pasti mengutuki Engkau di hadapan-Mu" (2:5). Seperti dalam pasal 1, di sinipun Iblis menantang Tuhan menjatuhkan Ayub, sebab ia yakin bahwa dengan demikian pastilah Ayub akan mengutuki Tuhan dan meninggalkan imannya. Lalu Tuhan menjawab: "Nah, ia ada dalan kuasamu; hanya sayangkan nyawanya". Menurut Alden Gannett, hal itu berarti pagar pelindungan tetap ada, meskipun makin dipersempit. Allah mengizinkan Iblis mencibai Ayub lebih banyak lagi, namun kendali tetap ada di tangan-Nya. Tuhan telah menyatakan tegas: sayangkan nyawanya. $^{31}$

Allah memperluas batas tindakan Iblis terhadap Ayub. Pada pasal 1, Iblis mencobai Ayub sebatas pada harta yang dimilikinya, tidak atas diri Ayub sendiri.

\footnotetext{
${ }^{30}$ Ibid, 26.

${ }^{31}$ Gannett, Pengertian Tentang Sakit Dan Penderitaan Dari Kitab Ayub, 10.
}

Kini, pada pasal 2, Allah mengizinkan Iblis mencobai Ayub kembali atas dirinya (2:6). Iblis kembali menghampiri Ayub. Kali ini, Iblis menimpakan barah yang busuk dari telapak kakinya sampai ke batu kepalanya (2:7). Ayub sangat menderita kesakitan. Ia menggaruk-garuk badannya dengan sekeping beling, sambil duduk di tengahtengah abu (2:8). Menurut David Atkinson, Ayub pergi ke tempat pengasingan penderita lepra, tempat pembuangan abu. ${ }^{32}$ Menurut Alden Gannet, duduk di tengah abu merupakan lambang kesedihan yang amat sangat pada saat itu. ${ }^{33}$

Iblis menantang Allah dengan menyatakan bahwa Ayub akan mengutuki Allah jika dicobai. Allah mengijinkan Iblis untuk mencobai Ayub. Dalam pengalaman Ayub, yang tiba-tiba diserang oleh orangorang Syeba $(1: 15)$; kemiskinan yang amat ekstrim melalui lenyapnya unta dan kambing domba (1:16-17), kehilangan semua anaknya (1:19), dan kemudian penghinaan dalam perubahan status social—dari orang terkaya menjadi orang yang amat malang, miskin yang duduk di tengah-tengah abu sambil menggarukgaruk badannya dengan sekeping beling. Ditambah penyakit barah yang busuk menyerang sekujur tubuhnya dari telapak

\footnotetext{
${ }^{32}$ Atkinson, Ayub, 28.

${ }^{33}$ Gannett, Pengertian Tentang Sakit Dan Penderitaan Dari Kitab Ayub, 11.
} 
kakinya sampai ke ubun-ubunnya (2:7-8). Sekali lagi, dakwaan Iblis adalah keliru.

Terbukti di sini, bahwa Ayub tetap tekun dalam kesalehannya dan tidak mengutuki Allah seperti yang diduga oleh Iblis dan seperti yang ditunjukkan oleh istrinya. Kata mengutuki di sini "barakh" memiliki pengertian menghujat atau mengkhianati. Sikap keimaman yang dimiliki Ayub patut menjadi teladan bagi orang percaya saat menghadapi situasi yang serupa Ayub tanpa kehilangan iman apalagi menghujat dan mengkhianati Allah.

\section{2:9-10 Reaksi istri Ayub}

Dalam ayat pasal 2 ini, istri Ayub tampil. Tetapi dalam pasal 1, istri Ayub tidak tampil (tidak pernah disebut-sebut). Sekarang lingkup peristiwa itu diperluas, bukan hanya Ayub tapi juga lingkungan sosialnya. Keadaan yang begitu memprihatinkan ini, Ayub sungguh membutuhkan penghiburan. Sebaliknya, berkatalah istrinya,"Masih bertekunkah engkau dalam kesalehanmu? Kutukilah Allahmu dan matilah!” (2:9).

Menurut Alden Gannet, ada dua kemungkinan yang mendorongnya mengucapkan kata-kata tersebut. Pertama, mungkin istri Ayub tidak sampai hati melihat suaminya demikian menderita badani setelah kehilangan segalanya. Kedua, kesedihannya yang amat sangat membuatnya putus asa. Tapi apa pun alasannya, tanpa disadari ia telah membantu Iblis mencelakakan suaminya sendiri. Mestinya ia berpegang teguh pada imannya dan menguatkan suaminya, bukannya membiarkan diri hanyut dalam keputusasaan. ${ }^{34}$ Di dalam pasal 1 dan 2, tidak ada keterangan sama sekali bahwa istri Ayub mengetahui tentang percakapan Allah dan Iblis di balik semua peristiwa ini. Tapi mengherankan sekali bahwa ia juga menggunakan kata "kesalehan" seperti Allah ucapkan. Dan juga kata-kata yang diucapkan Iblis: "Kutukilah Allah dan matilah" (2:9).

Perkataan istrinya kepada Ayub sama seperti perkataan Iblis yang menghendaki Ayub mengutuki Allah (band. 1:11; 2:5). Secara implisit, istri Ayub melihat apa yang terjadi adalah akibat dari perbuatan Allah. Istri Ayub mempertanyakan keadilan Allah. Sebaliknya, Ayub menegur istrinya,"Engkau berbicara seperti perempuan gila! Apakah kita mau menerima yang baik dari Allah, tetapi tidak mau menerima yang buruk?" (2:10). Kini, Ayub bukan hanya kehilangan harta benda,

\footnotetext{
${ }^{34}$ Ibid, 13.
} 
anak-anak dan kesehatannya, tapi juga dukungan dari istrinya.

Ayub benar-benar sangat menderita dan terdesak, ia harus merekonstruksikan ulang tentang kesadarannya akan Allah selama ini (yakin Allah memberkati orang saleh) dan mencocokannya dengan keadannya itu. Kesadaran Ayub akan Allah yang selama ini benar-benar disorot. Dalam keadaan sangat kritis demikian, Ayub masih memiliki kesadaran akan Allah yang tinggi-dalam kesemuanya itu Ayub tidak berbuat dosa dengan bibirnya (2:10b). Jadi, Ayub dikatakan tidak berbuat dosa dengan bibirnya itu adalah dampak dari kesadaran akan Allah yang ada di dalam dirinya.

\section{2:11-13 Akhir penderitaan Ayub dan}

\section{kunjungan ketiga sahabatnya}

Ketika ketiga sahabat Ayub mendengar kabar tentang segala malapetaka yang menimpa dia, maka datanglah mereka dari tempatnya masingmasing, yakni: Elifas, orang Teman, dan Bildad, orang Suah, serta Zofar, orang Naama. Mereka datang untuk mengucapkan belasungkawa kepadanya dan menghibur dia (2:11). David Atkinson menyatakan bahwa para sahabat Ayub menyatakan dukacita mereka dengan cara yang lazim pada zaman itu. Mereka menangis dengan suara nyaring, mengoyak jubah mereka dan menaburkan debu di kepala. Selama tujuh hari tujuh malam mereka duduk di tanah bersama Ayub tanpa mengucapkan sepatah kata pun karena mereka melihat bahwa sangat berat penderitaannya $(2: 13){ }^{35}$

Kunjungan ketiga sahabat Ayub tersebut menunjukkan suatu persahabatan sejati. Tali persahabatan mengikat mereka dengan Ayub kendati Ayub dalam penderitaan dan malapetaka. Mereka bertindak tepat dengan penuh keprihatinan yang terwujud dalam kehadiran mereka kendati tanpa bicara. Dengan berdiam mereka telah menyatakan sesuatu lebih dari apa yang dapat diungkapkan dengan kata-kata, karena tidak ada yang dapat dikatakan.

\section{Teologi}

\section{Allah berdaulat atas segala sesuatu}

Allah berdaulat. Dalam Ayub 1:12 dan 2:6, dengan jelas dinyatakan bahwa Iblis tidak dapat berbuat apa-apa tanpa izin-Nya. Segala gerak-geriknya senantiasa di bawah pengawasan dan kendali-Nya. Setiap izin Tuhan itu selalu disertai suatu batas yang tertentu. Jika Tuhan membatasi kuasa Iblis yang hendak melakukan pencobaan terhadap Ayub, tentulah Tuhan

\footnotetext{
${ }^{35}$ Atkinson, Ayub, 36.
} 
bertindak demikian juga terhadap Iblis yang akan melakukan pencobaan kepada orang percaya di segala zaman (band. 1 Kor.10:13). W.S Lasor, D.A Hubbard dan F.W Bush mengatakan demikian: Iblis memperoleh izin masuk untuk mencobai Ayub, namun tunduk kepada kekuasaanNya yang tertinggi. Ayub 1:12 dan 2:6 ini menggambarkan kekuasaan Allah atas Iblis bahwa ia tidak dapat mencelakakan Ayub di luar batas-batas yang ditentukan-Nya $(1: 12 ; 2: 6) .^{36}$

Kepada orang yang mengikuti atau memegang hikmat tradisional, maka Kitab Ayub ini memperkenalkan Allah yang bebas (baca: berdaulat). Ia bebas mengizinkan ujian yang dilakukan oleh iblis dan tidak memberitahukan apa-apa tentang hal itu kepada orang yang diuji. Jadi, dengan sangat jelas bahwa Kitab Ayub ini menggambarkan Allah yang tidak terikat pada rancangan manusia atau pada pengertian manusia tentang diri-Nya. Apa yang Ia lakukan muncul dengan bebas dari kehendak-Nya dan sifat-Nya sendiri, tanpa pedoman yang harus disesuaikan-Nya.

Perlu juga kita pahami bahwa di dalam kedaulatan Allah tersebut terkandung di dalamnya adalah hikmat

\footnotetext{
${ }^{36}$ Lasor, Hubbrad, and Bush, Pengantar Perjanjian Lama, 140-141.
}

atau kebijaksanan-Nya yang sempurna. ${ }^{37}$ Ayub menerima semuanya dengan penuh iman. Hal ini menunjukkan bahwa iman Ayub bukan iman pasif, yang sekadar pasrah melainkan aktif menjalin hubungan pribadi dengan Allah. Kesadarannya akan Allah didasarkan kepada imannya yang teguh. Hal itu ditunjukkan Ayub dengan sujud menyembah Allah seraya berkata: "Tuhan yang memberi, Tuhan yang mengambil, terpujilah nama Tuhan!" $(1: 20-21)$

Semua peristiwa bukan kebetulan, tapi ada rencana Tuhan di dalamnya

Inilah pengajaran sentral kitab Ayub bahwa hadirnya penderitaan itu karena diizinkan oleh Allah, yang di dalamnya terkandung rencana-Nya yang agung bagi umat-Nya. Penderitaan Ayub ini merupakan tipologi yang mengantar pada penderitaan Kristus. Dia menanggung penderitaan yang disebabkan oleh dosa manusia, bukan diri-Nya. Dikatakan George Eldon Ladd yang dikutip Sonny Zaluchu, bahwa kematian Yesus adalah sebuah penebusan dosa. ${ }^{38}$ Dosa manusia

\footnotetext{
${ }^{37}$ Kalis Stevanus, "Analisis Pertanyaan Retorika Dalam Ayub 40:1-28," DUNAMIS: Jurnal Teologi dan Pendidikan Kristiani 2, no. 2 (April 23, 2018): 119, accessed April 7, 2019, http://sttintheos.ac.id/ejournal/index.php/dunamis/article/view/163. ${ }^{38}$ Sonny Zaluchu, "Penderitaan Kristus Sebagai Wujud Solidaritas Allah Kepada Manusia," DUNAMIS: Jurnal Penelitian Teologi dan
} 
menyebabkan Allah menderita di dalam kasih-Nya dan kemurahan-Nya. Maka dalam rangka itu, Allah membuat God's Grand Design dan salib adalah puncaknya. ${ }^{39}$ Inilah kedaulatan Allah atas ciptaan-Nya, termasuk berdaulat atas umatNya. Walaupun Iblis ingin menghancurkan manusia dan menjelekkan nama Tuhan, namun Dia adalah Tuhan yang lebih berkuasa —sebab Ia adalah Yang Mahakuasa, di mana maksud rencana-Nya atas umat-Nya tidak pernah dapat digagalkan oleh Iblis (band. 42:5).

Patutlah kita bersyukur sebab kita memiliki Kristus yang turut menderita melalui Salib sebagai bagian dari rencana Tuhan atas umat manusia. Pengalaman ini semestinya menimbulkan sebuah refleksi bagi orang Kristen, jika mau mengikut Kristus haruslah bersedia memikul salib, yaitu menderita karena nama-Nya, karena kebenaran. Sebenarnya Tuhan sangat mampu melindungi umat-Nya supaya tidak mengalami penderitaan $(1: 10)$. Tetapi Ia lebih fokus untuk melindungi karakter umat-Nya daripada melindungi apa pun juga. Tentu perlindungan-Nya sesuai dengan kedaulatan Tuhan, untuk kebaikan umat-Nya menurut pandangan-Nya.

Pendidikan Kristiani 2, no. 1 (November 4, 2017): 61, accessed April 7, 2019, http://sttintheos.ac.id/ejournal/index.php/dunamis/article/view/129. ${ }^{39}$ Ibid.
Di sinilah persoalannya, jika kesulitan hidup itu merupakan didikan Tuhan, bagaimana sikap orang percaya? Jika orang percaya menganggap berbagai macam peristiwa (baca: kesulitan hidup) yang menimpa dirinya itu hanyalah 'kebetulan' belaka, ia tentu akan menghadapinya dengan sikap tertentu. Sebaliknya, bila ia menyadari bahwa semua itu adalah didikan Tuhan, yang di dalamnya ada maksud rencana Tuhan, sikapnya pasti akan berbeda pula. Dari Kitab Ayub ini, orang percaya tidak boleh berkata dengan sembarangan bahwa perkara-perkara (baca: kesulitan hidup) itu terjadi secara kebetulan. Dengan demikian, dapat disimpulkan bahwa semua peristiwa yang menimpa dalam kehidupan orang percaya, bukan kebetulan, namun ada rencana Tuhan di dalamnya. Baxter berkata : "Karena Iblis tidak dapat berbuat apapun jika Tuhan tidak mengizinkannya, maka perbuatan Iblis itu dipakai-Nya untuk mendatangkan kebajikan justru bagi orangorang yang hendak dibinasakan oleh Iblis itu." 40

Pentingnya melakukan refleksi diri (1: 20-21)

"Maka berdirilah Ayub, lalu mengoyak jubahnya, dan mencukur

\footnotetext{
${ }^{40}$ Baxter, Menggali Isi Alkitab 2: Ayub s/d Maleakhi, 29.
} 
kepalanya, kemudian sujudlah ia dan menyembah, katanya: Dengan telanjang aku keluar dari kandungan ibuku, dengan telanjang juga aku akan kembali ke dalamnya. TUHAN yang memberi, TUHAN yang mengambil, terpujilah nama TUHAN!" (ay.21). Ayub menyatakan kesadarannya akan segala keberadaan materi adalah dari pemberian Tuhan. Dia menyadari bahwa ia telanjang keluar dari kandungan ibunya, tidak membawa sesuatu pun. Tuhanlah yang memberi segala yang dia miliki. Jadi Tuhanlah yang mempercayakan semua harta dan keluarga yang dimilikinya. Keyakinan itulah yang membuat Ayub menjadi sadar, bahwa tidak ada hak yang dimilikinya untuk mempertahankan semuanya itu. Dengan kata lain, Ayub hendak mengatakan bahwa Tuhanlah yang memiliki hak untuk mengambil kembali apa yang pernah diberikan-Nya kepadanya, dengan banyak cara. Kesadaran itu timbul dari diri Ayub, sebagai dampak dari kesadarannya akan Allah.

Selanjutnya dikatakan di dalam Ayub 1:22 dan juga Ayub 2:10: "Dalam kesemuanya itu Ayub tidak berbuat dosa dan tidak menuduh Allah berbuat yang kurang patut." Hal ini membuktikan karakter Ayub yang tidak menyalahkan Tuhan karena kondisi yang dialaminya saat itu. Karakter tersebut muncul karena pada dasarnya Ayub sangat menghargai kedaulatan Tuhan atas semua yang dia miliki. Pernyataan atau ungkapan Ayub "tidak berdosa" dengan bibirnya dapat disimpulkan bahwa selama dalam kondisinya yang sulit, Ayub tidak pernah melakukan yang hal tidak benar dalam arti mengutuk Allah (seperti yang diharapkan oleh Iblis dan juga istrinya $(1: 11 ; 2: 5,9)$. Kemudian ditegaskan lagi dalam kata hubung "dan" bahwa Ayub tidak pernah menuduh Allah melakukan yang kurang patut. Karakter Ayub yang teruji membuat dia mampu menjaga hidupnya tetap benar di hadapan Allah dalam kondisi terberat sekalipun. Melalui perenungan diri, Ayub dapat menerima semua hal yang terjadi dengan sikap penyerahan diri sepenuhnya kepada kedaulatan Tuhan. Sikap tersebut selaras dengan pengajaran Yesus di bukit tentang kebahagiaan orang yang bergantung sepenuhnya kepada Tuhan, atau yang dikatakan sebagai miskin di hadapan Allah. ${ }^{41}$ Sikap tersebut selain akan dapat memuliakan Tuhan juga membawa anugerah Kerajaan Allah kepada orang tersebut.

\footnotetext{
${ }^{41}$ Ruwi Hastuti, "Makna Ucapan Bahagia Dalam Injil Matius 5:1-12," Jurnal Antusias 2, no. 3 (May 1, 2013): 16-26, accessed March 21, 2018, http://sttintheos.ac.id/ejournal/index.php/antusias/article/view/44.
} 
Pentingnya sikap penyerahan diri, tidak menjadi putus asa ketika dalam kesulitan hidup (2:10)

Nampak penyerahan diri Ayub melalui pernyataannya kepada istrinya: "Apakah kita mau menerima yang baik dari Allah, tetapi tidak mau menerima yang buruk?" (2:10). Ayub telah mengalami kedukaan dan penderitaan yang sangat ekstrim, tetapi dalam kesemuanya itu Ayub memilih sikap penyerahan diri kepada kedaulatan Allah. Semua penderitaannya tidak melunturkan imannya, sebaliknya justru mengalami kesadaran akan Allah yang lebih dalam lagi.

Penderitaan juga selalu dikaitkan dengan Tuhan baik langsung maupun tidak langsung. Keadaan ini juga dapat membawa manusia untuk semakin menerima atau memberontak atau menuduh Tuhan berbuat yang kurang patut. Itu dipengaruhi oleh kesadaran diri seseorang akan Allah. Kesadaran akan Allah akan menentukan cara seseorang memandang hidup yang terlihat dalam perilaku maupun tindakannya. Orang yang memiliki kesadaran akan Allah yang tinggi dapat mengendalikan dirinya untuk tidak mempersalahkan Tuhan, sehingga persoalan hidup tidak menjadi penghalang untuk menemukan Allah di dalam kesadarannya. Pengenalannya akan Allah menjadikan Ayub lebih kuat dan mampu bertahan dengan penyerahan diri kepada Allah. Mengutip Bartolomeus Wahyu Kurni, ${ }^{42}$ Ayub dalam menghadapi penderitaan tidak sampai pada sikap penolakan Allah seperti ditunjukkan istrinya.

Itulah sebabnya, penting bagi orang percaya untuk memiliki pengenalan akan Allah. Dari proses pengenalan akan Tuhan tersebut akan menemukan perspektif ilahi yang berasal dari hubungan pribadinya dengan Tuhan, lalu mengarahkan pandangannya untuk bisa memahami permasalahan yang dialaminya sehingga dapat merenungkannya (refleksi diri). Ayub tidak bersikap destruktif tetapi memberi tempat bagi Tuhan-berserah diri dengan kooperatif dengan-Nya di dalam membentuk dirinya. Itulah yang menjadi sumber kekuatan yang menjadikan Ayub tidak putus asa dalam menghadapi penderitaannya. Ayub memperlihatkan kepada orang percaya masa kini bahwa sikap putus asa adalah keliru.

Karena itu, orang percaya tidak boleh berputus asa ketika dalam permasalahan seberat apapun. Teladanilah Ayub seperti yang dinasihatkan oleh Yakobus: "Saudara-saudara, turutilah

\footnotetext{
${ }^{42}$ Kurniadi, "Inspirasi Kisah Ayub Bagi Seorang Katolik Dalam Menghadapi Penderitaan."
} 
teladan penderitaan dan kesabaran para nabi yang telah berbicara demi nama Tuhan. Sesungguhnya kami menyebut mereka berbahagia, yaitu mereka yang telah bertekun; kamu telah mendengar tentang ketekunan Ayub dan kamu telah tahu apa yang pada akhirnya disediakan Tuhan baginya, karena Tuhan maha penyayang dan penuh belas kasihan" (Yak.5:10-11).

\section{KESIMPULAN}

Melalui analisis naratif terhadap Ayub 1-2 dapat disimpulkan bahwa dalam penderitaan orang beriman perlu menyadari bahwa Allah berdaulat atas segala sesuatunya, bahwa tidak ada sesuatupun yang terjadi di luar izin Allah. Segala sesuatu juga tidak terjadi secara kebetulan, tetapi semuanya sudah dalam rencana Allah. Oleh sebab itu pada saat mengalami penderitaan, orang percaya penting untuk melalukan perenungan dan penyerahan diri kepada Allah. Ketika orang percaya memiliki kesadaran akan Allah dalam penderitaan, maka ia tidak akan menjadi putus asa.

\section{DAFTAR PUSTAKA}

Atkinson, David. Ayub. Jakarta: Yayasan Komunikasi Bina Kasih/OMF, n.d.

Baxter, J. Sidlow. Menggali Isi Alkitab 2: Ayub s/d Maleakhi. Jakarta: Yayasan Komunikasi Bina Kasih, 1989.
Bullock, C. Hassell. Kitab-Kitab Puisi Dalam Perjanjian Lama. Malang: Gandum Mas, 2003.

Djogo, Emanuel. “Tinjauan Permasalahan Teodise Kitab Ayub Dan Relevansinya Terhadap Penderita HIV/AIDS." MELINTAS 33, no. 3 (2017): 342-369. Accessed April 5, 2019.

http://journal.unpar.ac.id/index.php/m elintas/article/view/3076.

Drane, John. Memahami Perjanjian Lama 1. Jakarta: Persekutuan Pembaca Alkitab, 2009.

Dyrness, William. Tema-Tema Dalam Teologi Perjanjian Lama. Malang: Gandum Mas, 1992.

Gannett, Alden A. Pengertian Tentang Sakit Dan Penderitaan Dari Kitab Ayub. Jepara: Silas Press, n.d.

Hastuti, Ruwi. "Makna Ucapan Bahagia Dalam Injil Matius 5:1-12.” Jurnal Antusias 2, no. 3 (May 1, 2013): 1626. Accessed March 21, 2018. http://sttintheos.ac.id/ejournal/index.php/antusias/article/vie $\mathrm{w} / 44$.

Hidayat, Elvin Atmaja. "Iman Di Tengah Penderitaan: Suatu Inspirasi TeologisBiblis Kristiani." MELINTAS 32, no. 3 (September 6, 2017): 285. Accessed April 5, 2019. http://journal.unpar.ac.id/index.php/m elintas/article/view/2695.

Kurniadi, Bartholomeus Wahyu. "Inspirasi Kisah Ayub Bagi Seorang Katolik Dalam Menghadapi Penderitaan." MELINTAS 31, no. 1 (July 22, 2015): 47. Accessed April 5, 2019. http://journal.unpar.ac.id/index.php/m elintas/article/view/1455.

Larosa, Arliyanus. Belajar Dari Kitab Ayub: Tegar Dalam Penderitaan. Bandung: Kalam Hidup, 1997. 
Lasor, W.S., D.A. Hubbrad, and F.W. Bush. Pengantar Perjanjian Lama. Jakarta: BPK Gunung Mulia, 2015.

Longman III, Temper. Job. Grand Rapids: Baker Academic, 2012.

Maiaweng, Peniel C.D., Christina Ukung, and Christina Ukung. "Apakah Rut, Perempuan Moab Adalah Penyembah TUHAN?" Jurnal Jaffray 16, no. 2 (October 3, 2018): 161. Accessed April 5, 2019.

http://ojs.sttjaffray.ac.id/index.php/JJ V71/article/view/308.

Stevanus, Kalis. "Analisis Pertanyaan Retorika Dalam Ayub 40:1-28." DUNAMIS: Jurnal Teologi dan Pendidikan Kristiani 2, no. 2 (April 23, 2018): 119. Accessed April 7, 2019. http://sttintheos.ac.id/e- journal/index.php/dunamis/article/vie $\mathrm{w} / 163$.

Tarmedi, P. A. Didi. “Analisis Naratif: Sebuah Metode Kristiani Hermeneutika Kitab Suci." MELINTAS 29, no. 3 (July 14, 2014): 331-360. Accessed February 25, 2018. http://journal.unpar.ac.id/index.php/m elintas/article/view/902/889.

Zaluchu, Sonny. "Penderitaan Kristus Sebagai Wujud Solidaritas Allah Kepada Manusia." DUNAMIS: Jurnal Penelitian Teologi dan Pendidikan Kristiani 2, no. 1 (November 4, 2017): 61. Accessed April 7, 2019. http://sttintheos.ac.id/ejournal/index.php/dunamis/article/vie w/129. 